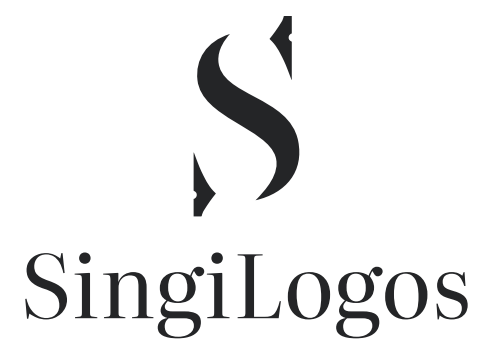

SINGILOGOS 2021, 1(1): 225 - 231

ISSN: $2812-7005$

UDK: 371:004.738.5

37.018.43:004.738.5

DOI: $10.18485 /$ us_singilogos.2021.1.1.17

Original paper/Originalni naučni rad

\title{
ШКОЛСКА ПРАКСА НОВЕ РЕАЛНОСТИ (НА ПРИМЕРУ ПЛАТФОРМЕ «УЧИ.РУ»)
}

\section{Марина Анатольевна Дрога ${ }^{1 *}$, Милош Пупавац ${ }^{2}$}

${ }^{1}$ Белгородски државни национални истраживачки универзитет, Русија

универзитет Сингидунум, Београд, Србија

\section{Апстракт:}

Педагози, а заједно и са њима ученици, постепено се преусмеравају ка новом образовном правцу. у раду је представљена анализа главних компоненти учења на даљину. Конкретно, разматрају се методе рада, типични задаци електронске образовне платформе Учи.ру. Дата је анализа задатака за ученике основних школа из обавезних наставних предмета. Такође, препоручују се практичне обуке за помоћ наставнику руског језика, математике и света око нас. Припреме за њих је боље водити заједно са наставницима. У контакту са одељењским старешином деца се региструју на платформу. Наставник региструје разред, и од тада може да користи ресурсе платформе за онлајн наставу, домаће задатке, такмичења, као и да користи видео материјале са часова чланова тима Учи.ру. Наставници у основној школи примећују велико интересовање малих истраживача за овај ресурс. Пре свега, то је повезано са логичним распоређивањем елемената дисциплине, занимљивим дизајном, аудио додацима, (звуци птица, представника животињског света, основних природних елемената), као и због блиске повезаности човека и природе. Испитују се чињенице из живота кроз игру. Дете се нађе уроњено у свет одраслих, овде су јасним језиком састављени и прилагођени кратки и информативни текстови, као и информације о природи. На платформи за учење дете ради својим темпом. Учи.ру анализира активности сваког ученика, прати грешке и успехе, стварајући индивидуалну образовну путању.

\section{Article info:}

Received: June 30, 2021

Correction: July 12, 2021

Accepted: August 5, 2021

\section{Кључне речи:}

учење на даљину, школски курс, основна школа, образовна технологија, електронска платформа Учи.ру. 
Догађаји последњих година преокренули су перцепцију друштва о стандардима. То се догодило у свим сферама живота, укључујући и образовање. „Научити да живимо на нови начин и у складу са реалношћу савременог света задатак је образовног система. Неопходно је преусмерити свест и квалитетно стећи нова знања и вештине не само међу младима, већ и међу људима старије генерације“." Кадар и њихова техничка опремљеност нису у потпуности спремни да одговоре изазову савременог времена. Наставници, а заједно са њима и ученици, постепено се преусмеравају на даљи образовни курс. „Били смо сведоци највећег образовног експеримента у историји човечанства, који је обухватио 90\% вртића, школа, колеџа и универзитета у свету. Укупан број ученика и студената премашио је 1,75 милијарди, плус више од 200 милиона наставника ".2

Као основне циљеве учења на даљину и онлајн-програма они који их разрађују виде у уштеди времена, једноставном коришћењу и могућности да се у било ком тренутку приступе интернету. „Коришћење дигиталних образовних ресурса има следеће циљеве: пружање могућности онима који уче да савладају образовне програме директно у месту где живе или привремено бораве; бесплатно коришћење различитих информационих извора за образовни процес у било ком тренутку погодном за ученика; јачање личне усмерености на процес учења; интензивирање самосталног рада ученика; јачање мотивације ученика ". ${ }^{3}$ Коришћење онлајн платформи у образовним институцијама помаже у уштеди времена, материјалних ресурса, људских ресурса у наставника који држе обуке за стицање знања, вештина и умења". ${ }^{4}$ У новом дигиталном простору показало се да се највише тражи руска онлајн платформа Учи.ру (https://учи.ру).

Платформа нуди задатке за ученике од 1. до 11. разреда из руског језика, математике, света око нас, енглеског језика и програмирања. У последњих годину дана примећен је пораст електронских извора и видео часова о књижевном читању и финансијској писмености. Ако говоримо о цени производа, онда је могућност коришћења ове платформе прилично једноставна: 20 бесплатних вежби дневно. Уколико родитељ може да плати неограничен приступ онлајн задацима (уз велики попуст), тада се детету даје корак по корак приступ свим врстама задатака и приступ образовним играма. Сверуски испитни тестови су урађени из основних предмета: руског језика, математике и света око нас. Припрему за њих је боље урадити заједно са наставником. У контакту са одељењским старешином ученици се повезују на платформу. Наставник региструје разред, затим може да користи ресурсе платформе за онлајн наставу, домаће задатке, такмичења, а такође и видео предавања тима „Учи.ру“.

1 Шнејдер 2019. URL: https://cyberleninka.ru/article/n/obrazovatelnye-innovatsii-pozitivnoe-i-negativnoe/ viewer (датум приступа: 31.10.2020).

2 Кондаков, 2020 URL: https://vogazeta.ru/articles/2020/6/26/Iniciativa_FGOS_40/13654-uroki_pandemii_novaya_realnost (приступљено: 07.09.2020).

3 Гайдамака 2019, 74.

4 Фортигина 2019, 204. 
„Савремени наставник мора имати ИКТ компетенције, мора бити оспособљен да користи наставне материјале интерактивних образовних платформи као допуну традиционалном образовању. У раду са интерактивном онлајн платформом, задатак наставника постаје неопходност одабира материјала који одговара предмету и уведе га у образовни процес ". ${ }^{5}$

Детаљније ћемо се задржати се на онлајн платформи Учи.ру, за разлику од претходно разматране технологије која се непрестано развија и живи. Ресурс је направљен за основну школу (од 1. до 4. разреда), заједно са егзактним наукама, укључује и област „Свет око нас“. Наставници у основној школи примећују велико интересовање малих истраживача за то. Пре свега, ово је због логичне конструкције елемената дисциплине, занимљивог дизајна, дубоке звучне пратње (звуци птица, представника животињског света, природних елемената), као и због блиског контакта човека и природе. Чињенице из живота се проверавају на разигран начин. Мали човек је уроњен у свет одраслих, овде су, разумљивим језиком, састављени и прилагођени, информативни кратки текстови и информације о природи. Последњих година природне науке су постале веома популарне у поређењу са почетком 21. века.

Размотрићемо један од структурних елемената система. Дакле, одељак „Понављање 3. разред“ укључује блокове „Свет око нас“, „О мени“, „Друштво“, „Тела и супстанце“, „Биљке“, „Животиње“, „Безбедност“, „Економија“ . Осећања и бриге својствена човеку разматрају се у подгрупи „Богатство унутрашњег света“. Увежбавању знања о човеку посвећен је блок „О мени“. Он садржи следеће компоненте: „Људски организам“, „Унутрашњи органи/Физиологија", Хигијена, анатомија/Група наука“, „ Системи органа“, „Мерење висине и телесне тежине“. Блок „Свет око нас“ садржи неколико задатака: „Природа“, „Екологија“, „Заштита природе“, „Земљиште“, „Природа родног краја“, „Гљиве“ и „Велико кружење материје и живота“.

Следећи структурни елемент - „Природа“ - садржи основне информације о географији, позива ученике 4. разреда да провере своја знања у вежбама: „Равнице и планине Русије“, „Мора, језера и реке Русије“, „Природне зоне Русије“ , „Зона арктичких пустиња“, „Тундра“ и „Шуме Русије“. Елемент „Историја“, такође је обухваћен одељком „Свет око нас“, представља само једну подгрупу „Светска историја“. У суштини, ово је почетак историје човечанства, полазна основа за следећи ниво школовања, односно за предмет „Историја“. На тај начин, онлајн платформа, креирајући и објављујући задатке за своје кориснике, не само да их тематски обједињује у групе и блокове, већ их усклађује са наставним програмима.

Одељак "Руски језик" садржи главне информације из школског програма. У њих су унети задаци општег карактера. Сви задаци су распоређени по темама, управо: баш по врстама речи. Задатак прилагођавања теми, а затим: пословним дијалектом. Низ електронских задатака започиње Цар-глагол. Вежбе су овде одабране на такав начин , да су све карактеристике руских глагола представљене у потпуности: време, род, инфинитив, вид, конјугације, начини. У одвојеном делу се приказују творбене могућности глагола, а такође се разрађују вештине морфолошког рашчлањивања.

5 Фортигина 2019, 205. 
Следећа тема су предлози, затим бројеви, а затим следе прилози као врста речи. Категорија као што је „категорија стања“ у делу за 4. разред не постоји. Речи које означавају различита стања особе сматрају се прилозима (увредљиво, болно, досадно итд.).

Након завршетка потребних радњи следи анимирани скеч, која обавештава за прелазак у следећу фазу. Гласовна подршка која прати која прати учење омогућава ученику да схвати ефекат проласка кроз „авантуру“. На екрану се појављују се натписи-оцене који смењују једни друге , наизменично: „Одлично“, „Сјајно“, „Задивљујуће“, „Супер“, „Није лоше“. Систем оцењивања направљен је тако да најкраћим путем доведу ученика до тачног решења, али уз самостално закључивање и размишљање. Задаци се граде према следећој шеми: у облику укрштених речи, у облику тражења потребних информација, састављања речи од слова. Сви они су усмерени на анализу чињеница, њихово уопштавање и проналажење сличних или различитих карактеристика. На платформи практично нема задатака у форми теста, што је додатна предност Учи.ру у поређењу са масом других платформи које тестирају знање у облику теста.

На образовној платформи дете ради својим темпом. Учи.ру анализира поступке сваког ученика, прати грешке и успехе, стварајући индивидуалну образовну путању. „Пројекат је веома популаран код деце, чини их паметнијим, доприноси личном напредовању ученика“, чак је и приметна промена атмосфере у одељењу. О томе сведоче резултати контролних провера и прегледи деце и њихових родитеља 2“. ${ }^{6}$ Са огромним интересовањем деца учествују у онлајн такмичењима на платформи Учи.ру. На примеру неколико задатака размотрићемо типове такмичарских вежби из Света око нас за ученике 4. разреда.

Такмичењу „Заврики“ на платформи Учи.ру претходи пробни круг, доступан за решавање током две недеље. Тада почиње почетак главне рунде. Задаци такмичења активни су 40 минута. У разматраном такмичењу представљене су 4 вежбе. Истичемо да садржај задатака одговара представљеном програму на платформи, као и нивоу знања који одговара школском програму за четврти разред. Називи вежби које је потребно решити садрже игровне елементе, који их приметно разликују од осталих и привлаче ученике узраста 9-10 година на ову платформу.

Свака од њих укључује видео материјал или звучни запис за јасно разумевање младих корисника, што олакшава решавање. Шта дете треба да уради у одређеном задатку - можете сазнати из предговора. Треба рећи да су задаци које су одабрали креатори платформе уједначени у оптерећењу, што значи да је за сваки задатак дато приближно 4 минута. Из овога следи да би ученик четвртог разреда требало да може брзо да ради на тастатури, да буде самопоуздан корисник и да се сналази у написаном тексту.

Такмичарски задаци садрже информације о странама света, временској прогнози, фазама производње материјала, путоказима, чак се нуде и нестварне животиње. Ученик треба да крене у потрагу како би одабрао тачан скуп особина карактеристичних за ту егзотичну звер (шта зна да ради, шта једе, где живи итд.).

6 Гильмутдинова 2019, 127. 
Зимско Дино такмичење је актуелно данас. „Дино“ легенда са острва Знања је интердисциплинарно онлајн такмичење из четири предмета: математика, руски језик, свет око нас и предузетништво. Задаци олимпијаде тренирају логику, пажњу и способност самосталног расуђивања. Задаци су усмерени на развијање нестандардног мишљења и реализују се кроз игровне активности које деца могу да разумеју. Креатори платформе истичу необичан формат такмичења ове године. Оно се ипак састоји од задатака из четири предмета, али уместо списка задатака, деца ће морати да прођу кроз низ соба за игре. Потрага је заснована на причи о крађи Камена Мудрости коју је починио Император Злоћа. Прво ученици треба да прођу обуку на острву Знања, а затим да реше задатке главног круга и врате камен. Авантуристичка природа тестова, пуна изненађења, даје образовном окружењу елементе микросвета у ком ученик осећа да је храбри ратник. Као крајњи резултат борби на трновитом путу до знања је дуго очекивана награда.

Новина описане платформе је увођење новог курса „Магична математика“, који је намењен ученицима четвртог разреда, то је нов формат учења. Обухвата задатке у складу са школским програмом, али у игровној и интерактивној форми. То је својеврсни и јединствен дигитални програм који представља сам по себи и стратегију. Ова дигитална забавна апликација обећава деци занимљиву причу, весело озвучивање, задаци садрже адаптивне нивое сложености, све већи проток информација, повећање брзине проласка кроз собе („прилагођавање“), прелазак играча на нови ниво - тзв. „пумпање“. „Магична математика“ даје ученицима прилику да утврде материјал из уџбеника, при томе озвучавање фрагмента обављају различити ликови (Мониторио, Слизни, итд.) Игра такође садржи такмичења у облику дуела са другим играчима који су истовремено на мрежи, односно са својим вршњацима. Истовремено истичемо да јунак не користи ниједну врсту оружја. Његов мач поседује само магију, што значи да магично скида чаролију са магичног камења које играчу даје снагу и кретање напред.

Током ове игре креатори су смислили и подстицање ученика речима, на пример: „Браво“, „Врх“, „Ти знаш шта радиш“, „Успео си!“ и други. У игри ће деца морати да уче у магичној школи и улазе у битке са противницима, путују кроз магичне димензије. Школарци се могу окушати као млади предузетници: зарадити новац, купити одећу и друге помоћне предмете од зарађеног новца, побољшавајући тако своју позицију.

Током проласка кроз курс из математике, млађем ученику се пружа прилика да активира магично камење, поправи робота-помоћника. Порука креатора игре деци звучи овако: „Научите математику и победите противнике!“ Такве речи су сасвим у складу са трендовима времена. Сами ученици оцењују ову игру са девет бодова од десет могућих. То указује на брзо растућу улогу игре у настави у нижим разредима основне школе.

Велики плус, а истовремено и пригодан бонус за рад, платформе је издавање наградних материјала. На дан завршетка олимпијаде и пријема резултата, на мејл родитеља шаље се диплома у којем се наводе име, презиме и образовна установа њиховог детета. Такви побољшани елементи награђивања су бесплатни и могу се брзо и лако наћи у ученичком портфолију (на личном налогу). 
Предност платформе описане у раду је висококвалитетан и занимљив материјал који се може користити као допуна традиционалном образовању. Поред тога, платформа Учи.ру омогућава индивидуалну обраду стеченог знања од стране сваког ученика, омогућава учешће на сверуским такмичењима ". ${ }^{7}$ Недостатак ове електронске платформе може се сматрати ограничавање бесплатних задатака који се нуде у износу од 20 картица дневно.

\section{БИБЛИОГРАФИЈА}

Гайдамака Е. П. (2019): Использование российских онлайн-платформ и образовательных ресурсов в современной школе. Горно-Алтайск // Информация и образование: границы коммуникаций. №11, 73-74.

Гильмутдинова Е. В. (2019): Использование образовательной платформы ЯКЛАСC и UCHI.RU в начальных классах // Интернет-технологии в образовании: сб. матер. Всероссийской научн.-практ. конф. / Отв. ред. Н. В. Софронова. 126-128.

Кондаков А. Уроки пандемии: новая реальность [Инернет ресурс]. URL: https://vogazeta.ru/articles/2020/6/26/Iniciativa_FGOS_40/13654-uroki_pandemii_novaya_realnost (приступљено: 07.09.2020).

Куксин И. Н. (2018): Цифровое образование - новые реальности. Экономика. Право. Общество. № 1(13), 36-41.

ОБРАЗОВАТЕЛЬНАЯ ПЛАТФОРМА "УЧИ.РУ" // ПедагогическиЙ поиск. 2017. № 1. С. 55.

Фортыгина С.Н. (2019) Об актуальности применения образовательных онлайн-платформ в начальной школе. Информационные технологии. Проблемы и решения. №1 (6), 204-208.

Шнейдер Л. Б. Образовательные инновации: позитивное и негативное. [Инернет ресурс]. URL: https://cyberleninka.ru/article/n/obrazovatelnye-innovatsii-pozitivnoe-i-negativnoe/ viewer (приступљено: 31.10.2020).

7 Фортигина 2019, 208 


\section{SCHOOL PRACTICE OF THE NEW REALITY (ON THE MATERIAL BY ELECTRONIC PLATFORM «UCHI.RU»)}

\begin{abstract}
Summary:
Teachers, and along with them, students are gradually being converted to a new educational course. This paper presents an analysis of the main points of distance learning. In particular, the work methods and typical tasks of the electronic educational platform are considered. An analysis of exercises for primary school students in basic subjects is provided. Training practices are also recommended to help teachers of the Russian language, Mathematics and the Natural Sciences. It is better to prepare for them alongside the teacher. In contact with the class teacher, the children are also connected to the platform. The teacher registers the class, and can then use the resources of the platform for online classes, home preparations, regional competitions, as well as use the materials of the video lessons of the UCHI.RU team. Primary school teachers note the great interest of young researchers in this resource. First of all, this is due to the logical construction of the elements of the discipline, interesting design, deep sound (sounds of birds, representatives of the animal world, natural elements), as well as the close contact of man with nature. Life's truths are tested in a playful way. A young person is immersed in the adult world, here adapted information mini-texts, information about nature compiled using clear language. On the educational platform, the child is engaged at his own pace. UCHI.RU analyzes the actions of each student, tracks mistakes and successes, thereby creating an individual educational trajectory.
\end{abstract}

Keywords:

distance learning, school course primary school educational technology electronic platform UCHI.RU. 